\title{
ISLAM AND THE PLIGHT OF INTERNALLY DISPLACED PERSONS (IDPS) IN IDP CAMPS IN ABUJA, NIGERIA
}

\author{
Suleiman B. Mohammed, Rafatu Abdulhamid \\ Department of Sociology University of Abuja, Nigeria \\ Department of Islamic Studies University of Abuja, Nigeria \\ Email: sbalamohammed@gmail.com,rafatuabdulhamid2014@gmail.com
}

\begin{abstract}
The paper is based on a study conducted on the Plight of Internally Displaced Persons (IDPs) in Abuja, Federal Capital Territory, Nigeria. The study sought to find out the socio-economic and psychological conditions of three IDP camps in Durumi, Karmajiji and Dakwa, and the extent of state and non-state actors support to the camps. Data was sourced through key Informant Interview, Focus Group Discussion and documents. The IDPs lacked access to quality bygiene, education and bealth services and found to be distressed and traumatized. The study found little support from the state, but enormous contributions from NGOs and philanthropists. The study recommends among others that IDP camps should be taken over by the state to provide basic amenities and empowerment.
\end{abstract}

Keywords: Internally displaced persons, Islamic values, Livehood.

\section{INTRODUCTION}

In the last two decades, Nigeria has been ravaged by insecurity occasional by Boko Haram insurgency in the northeast region and of ethno-religious crisis in north-central region. At the height of the insurgency, Boko Haram took some territory. These have caused massive internal displacement. Internally Displaced Persons (IDPs) camps were established in places of relative safety. Also, schools, uncompleted buildings by private individuals, empty government buildings were converted into camps. IDPs have also been shattered by friends and relations.

Although, Abuja, the Federal Capital Territory is located in the North-Central region of Nigeria, the epicenter of ethno-religious crisis, the territory is relatively safe. Therefore, displaced persons have trooped into the territory to be sheltered in camps and with friends and relatives. Consequently, there are a number of informal camps established in the territory by non-governmental organizations. IDP camps are supervised by the National Emergency Management Agency (NEMA), and supported by the government and non-governmental bodies.

IDPs have been compelled to leave their homes to safe places as a result of conflicts and faced numerous challenges including accommodation, access to food, education, health and their security and safety. Upon safe arrival at their new but temporary location, IDPs have basic needs to be met to live a decent live including shelter, water, food, health, clothing, security, information and so forth. 
The displaced persons have lost their source of livelihood, resources and savings to disaster and other hardship ${ }^{1}$ and therefore need support to restart their lives.

The IDPs appear to have no voice and obtain little assistance and are denied opportunities to design and monitor activities that affect them and their children. Further, mothers and girls in displacement are exposed to all sorts of atrocities and exploitation that includes rape, sexual violence and discrimination ${ }^{2}$.

This study therefore examines the plight of IDPs in Abuja, FCT, in terms of their shelter and access to food, education, health care, water and sources of livelihood. The level of support extended to them by the government and other non-governmental actors in resettling them and providing conditions that give them comfort and encourage their safe return.

\section{CONCEPTUAL FRAMEWORK}

The United Nations report, guiding principles on Internal Displacement defines internal displacement as forced migration from a place of crises to another of relative safety while Internally Displaced Persons (IDPs) are:

Persons or groups of persons who bave been forced or obliged to flee or to leave their homes or places of habitual residence, in particular as a result of or in order to avoid the effect of armed conflict, situation of generalized violence, violation of human rights or natural or man-made disasters, who have not crossed internationally recognized border ${ }^{3}$.

Internal Displaced Persons are those who flee their homes to avoid effect of armed conflict, situation of generalized violence, violation of human rights or natural or man-made disasters ${ }^{4}$. The UNCHR report of 2016 reveals that internal displacement is a global crisis. There are 65.6 million forcely displaced persons worldwide out of which 25.5 million are refugees while 40.3 million are internally displaced by conflict and about 2.8 million are seeking asylnn ${ }^{5}$. The IDPs face various challenges including security, access to basic services, education, health and violation of their rights ${ }^{6}$.

Studies have found that IDPs prefer to seek shelter with relatives rather than live in camps. They seek refugee with family, friends or host communities in areas where their ethnic or religious groups is in majority ${ }^{7}$. Similarly, $\mathrm{UNHCR}^{8}$ found that many IDPs were not found in camp but seek shelter where possible including railway station, aluminum containers, abandoned buildings and urban slumps. Also, 91.4 percent of IDPs displaced in 2014 live with their relatives while 7.6 percent stay in camps?

\footnotetext{
${ }^{1}$ Crisp, J. (2010).Forced Displacement in Africa: Dimensions, Difficulties, And Policy Directions. Refugee Survey Quarterly, 29(3), 1-27, doi:10.1093/rsq/hdq031.

${ }^{2}$ Benjamin, J.A., \& Fancy, K. (1998). The gender dimensions of internal displacement: concept paper and annotated bibliography. New York: Office of Emergency Programmes, UNICEF

${ }^{3}$ UNHR (2018).Questions and Answers about IDPs. Retrieved January 12, 2018, from United Nations Human Rights: http://www.ohchr.org/EN/Issues/IDPersons/Pages/Issues.aspx

${ }^{4}$ Ladan, M.T. (2006). Migration, Trafficking, Human Rights and Refugees under International Law: A case study of Africa. Zaria, Nigeria: Ahmadu Bello University Press.

${ }^{5}$ UNHCR (2016) Global Trends-Forced displacement in 2016 https://www.unhcr.org/ global trends

${ }^{6}$ Cohen, R., \& Deng, F.M. (1998).Masses in Flight: The Global Crisis of Internal Displacement. Washington, DC: Brookings Institution Press.

7Je'adayibe, G. D. (2008). "Religious Conflicts and Internally Displaced Persons" in Nigeria (in Population Movements, Conflicts, and Displacement in Nigeria. In T. Falola, \& O. O. Okpeh
} 
The full scope of IDPs in Nigeria is unknown due to limited capacity of the state to collect data and the complex nature of displacement ${ }^{10}$. Where data exists, they are mere estimates and inaccurate because of the dynamic nature of internal displacement ${ }^{11}$. However, Obikaeze and Onuoha 2016 projected that Abuja host 15,154 IDPs in 2,510 IDP households with household size of $6^{12}$.

\section{METHOD}

The scope of the study is the three IDP camps in Abuja Municipal Area Council of the Federal Capital Territory, Abuja, Nigeria located in Durumi, Karmajiji and Dakwa. Durumi IDP camp is located in Area I District of the city, near Old Secretariat by Dunamis Redeem Church, Garki, Abuja.It was established on $15^{\text {th }}$ February, 2014 with a population of 2,740 as at $2017^{13}$. It has a support group and is populated by IDPs from North-Eastern states of Borno, Yobe and Adamawa. The camp consists of tents and make-shift shelter surrounded by residential buildings and public offices. It has a primary school and clinic built by philanthropists and NGOs.

The Karmajiji camp is located a few kilometres from Abuja city gate. It is located in remote area of the suburb and consists of $500 \mathrm{IDPs}^{14}$. The camp is also populated by people from North-East states. It has a Nursery and Primary School in temporary structure where children are taught both Islamic and primary education. The camp is a make staff accommodation with tents.

Dakwa IDP camp is located in Dakwa, a small town, in AMAC. The IDPs are sheltered by friends and relatives as well as rented apartments. There is no special school or clinic, for IDPs, rather, they accessed education and health services from the community.

The study population comprises of IDPs in three camps. The scope of the issues are mainly on the plight of IDPs in three camps in respect of their shelter and access to food, health, education, water and their political rights.

The data for the study were obtained through secondary sources in the form of documents from agencies such as NEMA and NGOs as well as primary sources through focus group discussion (FGD) with male and female IDPs and key informant interviews (KII) with IDP leaders and head of government and non-governmental organizations. Qualitative technique of data analysis was employed.

${ }^{8}$ UNHCR. (2001). "Report of the UNCHR" On the human rights situation in Colombia - Organization of Work. Geneva, Switzerland: United Nations High Commissioner for Human Rights

'UNHCR. (2011). "Protecting refugee women". Promoting gender. Geneva, Switzerland: United Nations High Commissioner for Refugees. Retrieved from http://www.unhcr.org/4de4f71a9.pdf

${ }^{10}$ Egwu, S. (2011). "Ethnic Crisis and Internal Displacement in Nigeria". Socio-Political Dimensions and Solutions. Multi-Stakeholders Conference on Internal Displacement in Nigeria. Abuja: The Civil Society Legislative Advocacy Centre (CISLAC).

${ }^{11}$ Durosaro, I.A, \&Ajiboye, S.K. (2011): Problems and Coping Strategies of Internally Displaced Adolescents in Jos Metropolis, Nigeria. International Journal of Humanities and Social Sciences, 1(20), 256-262

12Obikaeze, V. C., \& Onuoha, C. B. (2016). “The Nigerian-State and Management of Internally Displaced Persons" (IDPs) From 2012-2016. African Journal of Politics and Society, 4-21. Retrieved from http://www.academix.ng/documents/papers/1484040429 7936.pdf

13Durumi Camp Association Phamlets 2017

${ }^{14}$ Karmajiji Camp Association Pamphlets 2017 


\section{PLIGHT OF IDPs}

\section{Nature of the Camp}

The three camps are informal settlements comprising of tents and make-shift shelter. IDPs also live with their friends and relatives, especially in Karmjiii and Dakwa. The average number of household is between 6-7 persons. The IDPs made their tents in all the three camps. A few households live in rented tents in Karamajiji camp while a few rented houses were found in Dakwa. The IDPs in all the camps faced enormous challenges of leaking roof and flooding during the rainy season.

The respondents generally felt dissatisfied with their shelter and expressed fear over the type of shelter they lived in due to the danger surrounding it, particularly during rainy season. A focus group discussion (FGD) male respondent from Dakwa noted:

Our accommodations are dilapidated and congested which caused severe sickness, especially to our children. The tenets were made from wood and due to long stay are infected by maggots.

Another FGD male respondent from Karamajiji lamented the quality of their shelter. He argued that:

The rooms are small and overcrowded with average number of household 7-8 family members, sometimes, there are up to 10 members in a tent. Most family members sleep on mats and leather.

The condition of our accommodation is sub-human.

Even where IDPs rented rooms like in Karamajiji and Dakawa, there are fears about upcoming rents and threats of eviction by landlords. In Karamajiji, male respondent maintained that:

We in Karamajiji, felt threatened by both our landlords and the Government. We learnt that the government will demolish our tents while our landlords will throw our things outside if we don't pay as at when due ${ }^{15}$.

IDPs in Abuja camps being an informal camp not officially recognized by the government is temporary, inadequate and lacked comfort. The tents are congested and limited in space to provide for decent accommodation. Some of the IDPs remember with regret how they were forced to live their accommodation to now live in substandard tents with enormous challenges. According to John, an IDP in Durumi, shelter is a huge challenge. He noted:

$W e$ are caged in a small space with congested tents that accommodate between $7-10$ persons without good ventilation. The situation is severe during rainy season with leakages and rain falling into the tents. Mosquito and other reptiles usually have a field day while malaria and cold is very rampant, especially amongst children ${ }^{16}$.

The shelter of the IDPs are largely provided by themselves with little support from charitable individuals in their communities. The government has no official camp and therefore does not provided any support for their shelter.

\section{Feeding of IDPs}

Food continues to be the major need expressed by the majority of IDPs. They continue to fend for themselves with little support trickling from individuals and organizations. Male participate in all kinds of menial jobs available in the area while women

\footnotetext{
${ }^{15}$ Focus Group Discussion conducted on 11/1/2018 in Karmajiji IDP camp FCT Abuja Nigeria

${ }^{16}$ Focus Group Discussion conducted on 11/2/2018 in Durumi IDP camp FCT Abuja Nigeria

${ }^{17}$ Focus Group Discussion conducted on $11 / 2 / 2018$ in Durumi IDP camp FCT Abuja Nigeria
} 
participate in petty jobs like woven of hair and hawking of items to feed their families. Occasional support comes from non-governmental organizations including faith-based organizations with food supplies which are shared amongst IDPs depending on family size.

The quantity and quality of feeding are huge issues among respondents. A female respondent from Durumi Camp noted that:

Feeding was regular at the initial stage but it reduced with time. Our husbands are into menial jobs and they supply us with the little they have. Some IDPs have three meals per day while some have less; some IDPs depend on their neighbours within the camp. The quality of the food is generally poor ${ }^{17}$.

However, occasionally some support are provided by organizations who visits the camp with bags of rice, salt, palm oil, groundnut oil and other food items. They also provide other needs of the IDPs such as soap, omo and other detergents. These provisions were reported to be rare and inadequate. When these items are distributed, household only obtain small ratio that may not take them for more than two days.

The respondents were generally unhappy with the feeding in the camp and remembered with frustration where they came from before the crisis that forced them out. They argued that they were farmers who often have sufficient food which they complemented with trade within their communities. A male respondent in Karamajiii lamented that:

The situation about our feeding is pathetic and unfortunate. We hardly get sufficient food to cater for our needs. Children are malnourished and infected with hunger-related diseases. When we go out of the camp to look for job we don't get and therefore lacked the money to cater for our families. Sometimes, we depend on the small amounts that our wives get through their petty work within the community $^{18}$.

Similarly in Dakwa, the situation is not different as feeding remains the major concern of the IDPs. Even though, their host communities assist in feeding them, especially the children, the problems were real. The IDPs complained about inability to get three meals in a day and sometimes even go to sleep without food. A male respondent noted that:

We are bungry here because the sources of jobs are limited and there is no land for us to cultivate to source for our food. We are competing with other people to get jobs on construction site. Others are engaged in petty jobs like shoe maker and cutting nails all to make ends meet. We now realized that life was good for us before the crisis as we could feed on daily basis and on the kind of food we desire unlike now that we don't have control over our destiny ${ }^{19}$.

\section{Livelihood}

The IDPs in the three camps indicated that their livelihood activities include limited farming, renting motorbikes to carry passengers and petty jobs like cutting nails and shoeshining. Most of IDPs in Durumi, Karamajiji and Dakwa reported that they have been farmers prior to displacement. After displacement, most men could not have access to land for cultivation. Many IDPs expressed concern over lack of sufficient means of livelihood, with numerous IDPs, including many Women lamenting being idle and soliciting assistance to start earning a living. Women complained that even though they were taught different skills by

${ }^{18}$ Focus Group Discussion conducted on 15/2/2018 in Karmajizi IDP camp FCT Abuja Nigeria

${ }^{19}$ Focus Group Discussion conducted on 26/2/2018 in Dakwa IDP camp FCT Abuja Nigeria 
NGOs they however lacked the capital to start business. A female respondent from Karmajiji argued.

We are fed up with staying idle, we need capital to set up business so that we also assist our busbands in the upkeep of the family. We cannot feed well and send our children to school because we don't have the means ${ }^{20}$.

A male respondent in Durumi also argued:

We were active farmers prior to displacement and we were doing well, especially with feeding and taking care of our needs. Some of us were also involved in trade in communities before displacement. However, we are now helpless yet we have to cater for our families. We want the government to come to our aid by securing farm lands with fertilizer and insecticide for us. Government can also support us in trade and other means of livelibood so that we can live as human beings'.

\section{Amenities at the Camp}

Amenities such as toilets, steady water supply, kitchen and electricity were available in varied conditions in the three camps under study and were not sufficient to cater for all the needs of the IDPs. Pit latrine toilets were shared and found to have broken down in Durumi. A make-shift kitchen was found where IDPs create a section outside the tents to cook during dry season. However, when there is rainfall, they either cook inside the room for those who own kerosene stove or sleep without food. Electricity was found in the camp, however, the connection was irregular just as the power supply was also irregular, water through borehole was available in Durumi and Karamajiji, however, the borehole in Durumi was not functional during the time of our visit due to absence of generator to power the borehole.

A male respondent in Durumi noted that:

Our toilets are not in good condition, a philanthropist came and demolished all the toilets and started rebuilding new ones but unfortunately be could not finish the construction. At present we are stranded because of lack of convenience. Some of us go to the bush to ease ourselves which is risky, especially at night ${ }^{22}$.

A male respondent in Karmajiji highlighted the challenge of access to water in the camp.

We have been living without access to portable water and have depended on buying water from vendors to cater for our needs. This is a problem for a people that have no stable job. Recently, an NGO called victim of violence dog a borehole and brought a generator to pump the water for us, we have enjoyed that water, however, the borehole and the generator developed some problems and have not been rectified. We now buy water for our needs from our megre resources ${ }^{23}$.

\section{SOCIO-ECONOMIC CONDITION OFIDPs}

\section{Education}

In two of the camps, Durumi and Karmajiji, primary school exist with temporary structure for the education of the children while Dakwa had no school designated for the camp. The school facilities were provided by NGOs as well as the payment of ad-hoc staff

\footnotetext{
${ }^{20}$ Focus Group Discussion conducted on 19/2/2018 in Karmajïi IDP camp FCT Abuja Nigeria

${ }^{21}$ Focus Group Discussion conducted on 11/2/2018 in Durumi IDP camp FCT Abuja Nigeria

${ }^{22}$ Focus Group Discussion conducted on 11/2/2018 in Durumi IDP camp FCT Abuja Nigeria

${ }^{23}$ Focus Group Discussion conducted on 22/2/2018 in Karmajiji IDP camp FCT Abuja Nigeria
} 
salaries. The children were expected to join public secondary schools on completion of their primary education while in Dakwa, the children were expected to join public primary school in the community.

Access to education by the children of the IDPs appears to be irregular and inconsistent in all the camps. Education depended on the assistance and support of NGOs and philanthropists for funding. There was no systematic approach to ensure access of children to school. School-age IDP children were left to the mercy of their parents with no state run education programme to ensure access to basic education. The quality of the schools were suspects as school building and facilities; tables, chairs and materials, chalk, duster were provided by NGOs and philanthropists which are often regular. Payment of staff salary has been a huge issue leading to teachers abandoning their classrooms.

The Chairman, IDP Association of Karmajiji narrated their plight in the area of education. He said:

Temporary school was built for us by Okorocha's son, it was expected to last for only six months and this months (March, 2018) makes the sixth and end of the school. The arrangement is that our children would be mainstreamed into government schools to continue but our problem is that most of us cannot afford the school charges. We are grateful to women for building Islamiyya school for us and employ teachers to teach them ${ }^{24}$.

In Durumi, NGO, especially Muslim Women Organization in Nigeria and others have been catering for the education of children. However, there are still challenges, the leader of the IDP Association sums up the situation.

We appreciate the efforts of some NGOs and organizations such as the Coalition of Muslim women organizations in Nigeria, NYSC, and so forth for building some classes for our children and they are really benefitting. Many of our children can read and write. The major problem is non-payment of stipend to the teachers who volunteer to teach the children. The teachers are not paid regularly. Infact, one of the widows who participated in the teaching had to withdraw due to none payment because she needed money to take care of her children ${ }^{25}$.

In Dakwa IDP camp, the Chairman of the camp Association corroborated the challenges Some philanthropists enrolled 40 of our children into school while majority of children are out of school since the time we left our homes. They cannot also attend Islamiyy because we cannot afford the fees ${ }^{26}$.

There is no formal arrangement to provide access to education for the children of IDPs in three camps in Abuja Municipal Area Council. The efforts of NGOs and philanthropists has not gone beyond primary education. The situation imply that the children had no access to Universal Basic Education and therefore likely going to grow as illiterates. This haddefeated the prospects of Universal Basic Education for all children and the realization of the sustainable development goal on access to education.

${ }^{24}$ Key Informant Information conducted on 22/2/2018 in Karmajiji IDP camp FCT Abuja Nigeria.

${ }^{25}$ Key Informant Information conducted on $11 / 2 / 2018$ in Durumi IDP camp FCT Abuja Nigeria 


\section{Health Care}

The IDPs lacked access to quality health care services. A clinic constructed by philanthropist exist in only one camp, Durumi, which appears more like a first aid centre. The clinic had no pharmacy and laboratory services. The services provided were found to be eractic depending on when the health personnel appear for work. The Chairman of Durumi Camp Association sums up the state of the health facility.

The clinic provides first aid services by nurses employed a philanthropist. It operates occasionally and lacked laboratory services and pharmacy. The health personnel are not available most of the time and close early whenever they come for duty. Patients buy their drugs from a nearby pharmacy shop outside the camp. We consider ourselves likely to have this medical facility which has helped in given first aid services and are grateful to the philanthropist ${ }^{27}$.

The other two camps in Karmajiji and Dakwa had no health facility dedicated to them. The Chairman of Karmajiji lamented the lack of a clinic for the camp. He noted:

We don't have any medical facility here in Karmajiji. Sick. IDPs are taken to the Karmajiji Community clinic where they are treated. The pay for their medical bills. Maternal health care is also provided at the community clinic. The major challenge for us is the exorbitant cost of modification... as you know our people are poor, unemployment and dependent ${ }^{28}$.

However, there is an arrangement between the Association of the camps and management of National Hospital in Abuja where sick persons are taken for treatment. The FCT Emergency Management Agency broker the arrangement and is responsible for payment of the medical bill. The officials of the camp Association informed us that the arrangement is not being honoured by the hospital due to unpaid accumulated bills.

The Chairman of Durumi and Karmajiji Camp Associations variously complained about the inability of the National Hospital to receive and treat their patients. They noted that all the Abuja IDPs through various camp Associations had our arrangement with FCT Emergency Management Agency (FEMA) for the treatment of IDPs with severe or referral medical cases. The arrangement worked for some time, however the hospital complained about nonpayment of medical bill by FEMA hence their inability to continue providing referred medical services.

All our FGD and KII informants were unanimous that access to health services is a major concern for the IDPs in the three Abuja camps. There is no coherent and systematic arrangement to cater for the health concerns of the IDPs. The situation is further compounded by the inability of the IDPs to cater for their health needs due to unemployment and poverty. The IDPs therefore do not have access to health care services, including material health care services.

\section{Politics and Governance}

Many of the IDPs in the three camps participated in politics in their homes prior to displacement. However, they lost their voters card and are not fully integrated into the politics of their new settlement. They acknowledged that politicians visit them occasionally, especially

\footnotetext{
${ }^{26}$ Key Informant Information conducted on 26/1/2018 in Dakwa IDP camp FCT Abuja Nigeria

${ }^{27}$ Key Informant Information conducted on 11/2/2018 in Durumi IDP camp FCT Abuja Nigeria

${ }^{28}$ Key Informant Information conducted on 19/2/2018 in Karmajiji IDP camp FCT Abuja Nigeria

${ }^{29}$ Focus Group Discussion conducted on 22/2/2018 in Karmajiji IDP camp FCT Abuja Nigeria
} 
during electioneering campaign to solicit for their support and often abandoned them after elections. Politicians access the IDPs through the leadership of IDP Associations. The main obstacle to their full participation is the lack of voters card, however, the Independent National Electoral Commission (INEC) has embarked on continuous voters registration. The IDPs indicated their readiness to register during the exercise.

A female respondent in Karmajiji camp still insists that they could not register after many futile attempts. She contended that:

We have been to the venue of the continuous voter registration several times but the INEC officials kept asking us to come back again and again. We got tired and did not go again. It appears that they were not ready to register us, since, several trips will also amount to buge transport cost which we can bardly afford ${ }^{29}$.

The Governance of the camps is done by a support group which oversees the administration of the camp. The Association also liases with government agencies and nongovernmental organizations to source, collect and distribute assistance extended to them. It also takes complaints to relevant government agencies for quick resolution and resolve conflicts amongst the IDPs. It also ensures security and safety of the camp. The Associations have a full complement of leadership structure with officials charged with specific responsibility. However, all positions were filled by men except the position of women leader which has been reserved for female. The women leader liases with the officials and women in the camp. Women appear to be marginalised in the governance structure of the camp. However, the women did not feel so as they think that the leadership are doing well and leaders always keep them abreast of governance and other related matters.

A female respondent in Durumi noted that:

We are happy and proud of our camp leaders. They have been representing us well and have brought government officials, NGOs and philanthropists who have supported us. Our leaders have been representing us well and we don't feel marginalized. We also a woman leader who liaises between the leadership and the women folk. We appreciate the great work they do and do not feel any sense of marginalization or neglect ${ }^{30}$.

This is hardly surprising since most of the Nigerian society is patriarchal where women have been socialized into gender roles.

\section{PSYCHOLOGICAL DISTRESS AND COUNTER-BASED VIOLENCE}

Many IDPs expressed having undergone severe psychosocial distress in escaping violence and still being experienced throughout displacement. Psychological support services are greatly needed to help families deal with such trauma.

A female respondent from Dakwa camp said:

I lived in Komura village in Kundiga LGA Borno State. I lost my sight in the process of escaping from Boko Haram violence. I am still not finding it easy in the camp ${ }^{31}$.

Another female respondent for Dakwa said:

I was abducted by Boko Haram and I stayed with them for about four months during this period, I

passed through series of torture because I refused to marry anyone amongst them. I managed to

\footnotetext{
${ }^{30}$ Focus Group Discussion conducted on 11/2/2018 in Durumi IDP camp FCT Abuja Nigeria

${ }^{31}$ Focus Group Discussion conducted on 26/2/2018 in Dakwa IDP camp FCT Abuja Nigeria

${ }^{32}$ Focus Group Discussion conducted on 28/2/2018 in Dakwa IDP camp FCT Abuja Nigeria
} 
escape from their violence. However, life in the camp although secured is still toughand full of deprivation ${ }^{32}$.

Respondents from FGD in Dakwa observed 'we are stigmatized by some people as they look at us as the Boko Haram people and they are unwilling to associate with us or to even render their assistance ${ }^{33}$.

Gender based violence was rare as respondents reported only one case of rape of an IDP child girl in Karmajiij. The case was prosecuted, the convict was punished and the parents of the raped victim were relocated to another environment. No incidence of rape or other forms of gender violence was reported in the two camps, Durumi and Dakwa.

However, some forms of gender discrimination was noticed among the IDPs. Leadership was documented by males while females were restricted to gender based work such as petty trading and hawking of goods. The females were not fully involved in decision making. There were no special provision for widows in the camps who often had to cater for themselves and their family.

\section{STATE AND NON-STATE ACTORS SUPPORT}

A number of state agencies and non-governmental organizations were involved in providing humanitarian relief to IDPs in Nigeria. The state agencies include National Emergency Management Agency (NEMA) and National Human Rights Commission (NHRC). The non-governmental organizations including faith-based organizations actively engaged in IDP issue in Nigeria include Nigerian Supreme Council for Islamic Affairs (NSCIA), Christian Association of Nigeria (CAN), Federation of Muslim Women Association in Nigeria (FOMWAN), Women in Da'wah (WID), and victim of violence among others.

Although, there is no official IDP camp in the FCT, various state agencies have assisted the camps in post-disaster management. They provide relief materials in forms of food and nonfood items. This is in addition to responsibility of conventional ministries who are saddled with statutory responsibilities. For instance, the ministries of education and health are expected to cater for the education and health needs of the IDPs. A Director in the National Emergency Management Agency maintained.

... the state has not established a formal camp in the FCT because of the fear of infiltration by bad elements. However, government is aware of the existence of informal camps and assist them with food and other materials as well as NEMA co-ordinates the assistance of government organization and non-governmental organizations in camp to ensure that the IDPs are well catered for ${ }^{34}$.

Another Director of FEMA, Engr. Ahmed, noted that the Agency is also responsible for the welfare of the IDPs through the co-ordination of the activities of the IDPs in the FCT. He observed that:

Part of the activities of FEMA is routine camp visitation. An officer is in charge of a camp and pays weekly or fortnightly visit, to such camp in order to listen to the complaints of IDPs and take care of them. They visit to provide relief and non-relief materials to the IDPs and contribute in camp

\footnotetext{
${ }^{33}$ Focus Group Discussion conducted on 29/2/2018 in Dakwa IDP camp FCT Abuja Nigeria

34 Interview conducted with Mr. Kayode Fagbemi on 11/2/2018 in National Emergency Management Agency (NEMA) FCT Abuja Nigeria

35 Interview conducted with Mr. Ahmad on 15/1/2018 in FCT Emergency Management Agency (FEMA), FCT, Abuja, Nigeria
} 
management through the camp Association. We also pay special attention to vulnerable IDPs, especially widows and children and provide them with special care ${ }^{35}$.

Similarly, the National Human Rights Commission (NHRC) are involved in the protection of the rights of the IDPs in camps. The Director, Monitoring Department of the Commission, Tony, argued that NHRC is actively engaged with IDPs to ensure the protection of the rights of IDPs. He noted:

Our mandate is to ensure that the means of livelihood, education, medical care, security of IDPs are all taking care of. We ensure that basic rights of IDPs are protected and have established a protection section working group in IDP camps. The Committee is made up of all stakeholders including UNHCR, ministries and national and international organizations. The Committee liaises with relevant stakeholders to ensure delivery of services ${ }^{36}$.

Visits to three IDP camps did not corroborate the alleged involvement of these organizations and ministries in the camps. The camps were constructed by the IDPs and their relations and the minimal structure for education and health where they existed were provided by non-governmental organizations. The state of education, health and hygiene in the camps did not show active involvement of ministries of education or health.

Non-governmental organizations, especially faith-based organizations have visible involvement in the three camps. They were reported to have provided food and other relief materials occasionally and were also involved in the areas of skill acquisition, health and education of the IDPs.

FOMWAN President, Maryam Abdullahi, noted that their organization have made several interventions in FCT IDP camps, especially in the areas of employment generation skills to prepare for the resettlement and integration back to their communities. She maintained that:

... we have established tutorial classes for secondary school students, primary school classes and Islamiyya and have implemented training in different trades for men and women in IDP camps in FCT. The IDPs were trained in soap making, tailoring, GSM repairs, shoe and bag making. We have mobilized substantial resources and disbursed same to various IDP locations in the FCT ${ }^{37}$.

The study found sufficient evidence of NGOs intervention in IDP camp especially in skill acquisition, education and health. However, the intervention has not been adequate enough to lift the IDPs from poverty and psychosocial distress occasioned by living in camp. Further, Victims of Violence Foundation has been involved in supporting IDPs nationwide. The Chairman of the Foundation Eng. Suleiman noted that they are concerned with coordinating and assisting victims of rape. They handled cases of rape to ensure justice for the victim. He contended that the foundation has done a few intervention in IDP camps in FCT.

... the Foundation build prefabricated classrooms in Bwari and Karmajiji. It supported the control of cholera outbreak in Karmajizi in 2016 through cutting the circle of spread by

\footnotetext{
${ }^{36}$ Interview conducted with Mr. Tony Ojukwu on 18/1/2018 in National Human Rights Commission (NHRC), FCT Abuja, Nigeria

${ }^{37}$ Interview conducted with Mariam Abdullahi FCT FOMWAN Amirah, on 11/2/2018, FCT Abuja, Nigeria.

${ }^{38}$ Interview conducted with the founder Victims of Violence - Charity Foundation Eng. Suleiman on Eng. Suleiman on 24/1/2018, Zone A4, Asokoro Abuja
} 
disinfecting all the water source through the use of water M100 chlorine generator and built a borehole in Karmajiji ${ }^{38}$.

The findings of the study confirmed that NGO intervention is improving the welfare of IDPs. However, it appears too little, superficial and uncoordinated to drastically reduce the suffering of the IDPs. The fact that the camps are not officially recognized imposes limit on the amount of official assistance they could receive from state agencies.

\section{Islamic Values as Antidote on the Plight of Internally Displaced Persons (IDPs) in IDP Camps in Abuja, Nigeria.}

Islam requires believers to assist and protect vulnerable people and offers a number of mechanisms for their care and support. According to Islamic law individuals have the right both to seek and to be granted protection in any Muslim state. Furthermore, it is the duty of Muslims to accept and protect refugees for as long as they seek protection. Islam embraces people of different races, nationalities and ethnicities.

The Qur'an says:

And if anyone of the disbelievers seeks your protection, then grant him protection so that he may hear the word of Allah, and then escort him to where be will be secure. (Q. 9:6)

The Qur'an also has numerous references to justice, particularly the importance of creating a just society, and provides a framework for justice in inter-personal relationships, toward the poor and needy, and connections between communities and nations. It speaks specifically to issues of justice surrounding refugee protection. These concepts were integral to the creation of Islam. In $662 \mathrm{AD}$, the Prophet Muhammad (SAW) migrated (hijrah) from Makkah and sought refuge in Madinah. This hijrah, or migration, came to symbolize the movement of Muslims from lands of oppression to those of Islam. Moreover, the hospitable treatment of Muhammad (SAW) by the people of Madinah embodies the Islamic model of refugee protection contained in the Qur'an.

Furthermore, Islam obliges host societies to give refugees/ displaced persons generous reception, for which the hosts will be rewarded. Allah says:

And the first forerunners (in the faith) among the Mubajireen and the Ansar and those who followed them with good conduct - Allah is pleased with them and they are pleased with Him and He has prepared for them gardens beneath which rivers flow, wherein they will abide forever. That is the great attainment. Allah has forgiven the prophet and the Mubajireen and the Ansar who followed him in the hour of difficulty after the hearts of a party of them had almost inclined (to doubt) and then He forgave them. Indeed, He was to them kind and Merciful (Q. 9:100 and 117).

Protection should be provided without discriminating between free persons and those who are enslaved, between rich and poor, men and women, or Muslims and nonMuslims. This responsibility is formalized in the fourth chapter of the Qur'an, which states that:

He who emigrates in the path of God will find frequent refuge and abundance (Q.4: 97-99)

Islam requires that host populations facilitate the voluntary return of refugees to their places of origin when considered safe. Such refuge remains inviolate even if the person 
who is being offered protection is in a conflict with Muslims (Q. 9: 6) Islam entitles refugees and internally displaced persons to certain rights and to humane treatment (Q.8: 72-75, 16: 41) and it condemns people whose actions prompt mass displacement, viewing them as lacking faith in Allah's words (Q.2: 84-86). The Qur'an also puts forth certain regulations to lend additional support to women and children, who are considered more vulnerable (Q.4: 2, 9, 36, $75,98,127,17: 34)$. Under the principle of justice, which is the basis of all Islamic regulations (Q.42: 15, 16: 90), those who are more at risk as a result of displacement should be offered extra support. This is also true of non-Muslims or those who oppose the Muslim faith (Q.5: 8].

Required alms, such as khums (one fifth of income or of the spoils of war that Muslims are required to hand out as charity) and zakat (a portion of property that the faithful are required to give away for charitable causes), as well as optional alms, constitute a fund that can be used to meet the basic needs of refugees/ displaced persons.

It is clear, therefore, that Islamic law encourages a humanitarian approach to refugees, asylumseekers and internally displaced persons.

\section{CONCLUSION}

The study has established that the IDP Camps in Abuja, FCT are informal and were established by IDPs and their relatives. The condition of the IDP camps in respect of shelter, amenities, feeding and livelihood is sub-standard. IDP camps are made up of tents and makeshift shelter while educational and health infrastructure and services were grossly inadequate to cater for the needs of IDPs. Some camps have no health and educational facilities and depended solely on neighbouring communities. Tents are congested, overcrowded and subhuman. The IDPs depended on support from state and non-state actors for food and other relief materials. Feeding was a major concern as IDPs can rarely feed adequately due to poverty and lack of job.

The socio-economic conditions of the IDPs especially in the areas of health, hygiene, and education are pathetic. Access to quality health care and education is non-existent. The education of children depended on NGO's intervention in the areas of health and educational facilities and payment of staff salaries. In Durumi, school teachers abandoned classes because salary had not been paid. Access to nearby basic education institution is difficult because of the inability of the IDPs to pay education levy and charges imposed on the children. Therefore, majority of children in the camps did not enroll in school on a sustainable basis. The situation is similar with health services. Sick IDPs go to nearby pharmacy shops to buy drugs often without prescription by a physician. Only one out of the three camps has a clinic whose operation depended on NGO and philanthropists. Therefore, medical services were obtained outside the camp. The IDPs have reported great difficulties in meeting their education and health bills.

The study found some cases of distress and trauma among the IDPs, some feelings of dejection and powerlessness arising from the conditions of life. This is not surprising considering the massive challenges they faced prior, during and after displacement. The study also found little state intervention on the plight of IDPs in the FCT. It appears the state is concentrating on formal IDP camps located in states in turmoil such as North-East states of Borno, Yobe and Adamawa. Also, the epicenter of the ongoing herders-farmers conflicts in 
North-Central states of Benue, Taraba and Nasarawa. State support for IDP camps in FCT was minimal and it was being anchored by the FCT Emergency Management Agency (FEMA) and National Human Rights Commission (NHRC). Others included relevant ministries and agencies such as health, education, environment and so forth. However, support of NGOs appears overwhelming in the areas of food and other relief materials, education, health and skill acquisition. The support seems inadequate to lift the conditions of the IDPs from their predicament. Consequently, a more systematic, coherent and organized intervention is required to address the plight of IDPs who are just recovering from disaster.

\section{RECOMMENDATIONS}

Government must transform the camps to official camps with relevant and appropriate shelter, school and skill acquisition facilities. Government should provide the required welfare for the IDPs, particularly, to ensure adequate feeding, means of livelihood, access to portable water and regular electricity supply. There should be access to quality hygiene and health. Relevant agencies of government should collaborate to ensure access and affordability of those services. The rights of IDPs as citizens must be protected. They should be empowered to exercise their franchise and indeed all other rights Non-governmental organizations, including faith-based organizations should channel their intervention on the needs and aspirations of the IDPs in a much more coordinated manner. Relevant government agencies should liaise with the IDPs through their Associations and the NGOs to ensure an orderly systematic care to ameliorate the poor condition of life of the IDPs.

The state should quickly resolve the underlying causes of conflicts, crises and displacement to halt further displacement and emergence of more IDP camps. Crucially, enabling conditions should be created for the IDPs to facilitate safe return to their homes. In Islam, whatever is necessary to enhance peaceful and meaningful existence of the community is considered a security measure for which every Muslim must work. Education and empowerment for the IDPs remain the famous catalysts for rapid growth, peace and development in our country. The Nigerian Islamic Scholars (Ulamab) through their various organizations should play an important role in countering the Boko Haram ideologies and any other deviant ideology that may lead to insurgency .

\section{Biographical Statement}

Suleiman B. Mohammed is a Professor of Political Sociology and Development in the Faculty of Social Science, Department of Sociology, University of Abuja, Abuja

Rafatu AbdulHamid is an associate professor of Islamic jurisprudence and gender studies at the Department of Islamic Studies, Faculty of Arts, also the program coordinator, Centre for Gender Security Studies and youth Advancement, University of Abuja.

\section{REFERENCES}

Benjamin, J.A., \& Fancy, K. The gender dimensions of internal displacement: concept paper and annotated bibliography. New York: Office of Emergency Programmes, UNICEF (1998).

Cohen, R., \& Deng, F.M. Masses in Flight: The Global Crisis of Internal Displacement. Washington, DC: Brookings Institution Press (1998).

Crisp, J. Forced Displacement in Africa: Dimensions, Difficulties, And Policy Directions. Refugee Survey Quarterly, 29 (3) (2010)., 1-27, doi:10.1093/rsq/hdq031. 
Durosaro, I.A, \&Ajiboye, S.K. Problems and Coping Strategies of Internally Displaced Adolescents in Jos Metropolis, Nigeria. International Journal of Humanities and Social Sciences, 1(20), (2011): 256-262.

Durumi Camp Association Phamlets 2017

Egwu, S. Ethnic Crisis and Internal Displacement in Nigeria: Socio-Political Dimensions and Solutions. Multi-Stakeholders Conference on Internal Displacement in Nigeria. Abuja: The Civil Society Legislative Advocacy Centre (CISLAC) (2011).

Focus Group Discussion conducted on 11/1/2018 in Karmaiji IDP camp FCT Abuja Nigeria

Focus Group Discussion conducted on 11/2/2018 in Durumi IDP camp FCT Abuja Nigeria

Focus Group Discussion conducted on 11/2/2018 in Durumi IDP camp FCT Abuja Nigeria

Focus Group Discussion conducted on 15/2/2018 in Karmaijiz IDP camp FCT Abuja Nigeria

Focus Group Discussion conducted on 26/2/2018 in Dakwa IDP camp FCT Abuja Nigeria

Focus Group Discussion conducted on 19/2/2018 in Karmaiiji IDP camp FCT Abuja Nigeria

Focus Group Discussion conducted on 11/2/2018 in Durumi IDP camp FCT Abuja Nigeria

Focus Group Discussion conducted on 11/2/2018 in Durumi IDP camp FCT Abuja Nigeria

Focus Group Discussion conducted on 22/2/2018 in Karmaiji IDP camp FCT Abuja Nigeria

Focus Group Discussion conducted on 22/2/2018 in Karmajiji IDP camp FCT Abuja, Nigeria

Focus Group Discussion conducted on 11/2/2018 in Durumi IDP camp FCT Abuja Nigeria

Focus Group Discussion conducted on 26/2/2018 in Dakwa IDP camp FCT Abuja Nigeria

Focus Group Discussion conducted on 28/2/2018 in Dakwa IDP camp FCT Abuja Nigeria

Focus Group Discussion conducted on 29/2/2018 in Dakwa IDP camp FCT Abuja Nigeria

Interview conducted with the founder; Victims of Violence - Charity Foundation Eng. Suleiman on 24/1/2018, Zone A4, Asokoro Abuja.

Interview conducted with Mariam Abdullahi FCT FOMWAN Amirah, on 11/2/2018, FCT Abuja, Nigeria

Interview conducted with Mr. Kayode Fagbemi on 11/2/2018 in National Emergency Management Agency (NEMA) FCT Abuja Nigeria

Interview conducted with Mr. Ahmad on 15/1/2018 in FCT Emergency Management Agency (FEMA), FCT, Abuja, Nigeria 
Interview conducted with Mr. Tony Ojukwu on 18/1/2018 in National Human Rights Commission (NHRC), FCT Abuja, Nigeria

Je'adayibe, G. D. "Religious Conflicts and Internally Displaced Persons" in Nigeria (in Population Movements, Conflicts, and Displacement in Nigeria. In T. Falola, \& O. O. Okpeh. (2008).

Karmajiji Camp Association Pamphlets 2017

Key Informant Information conducted on $11 / 2 / 2018$ in Durumi IDP camp FCT Abuja Nigeria

Key Informant Information conducted on 26/1/2018 in Dakwa IDP camp FCT Abuja Nigeria

Key Informant Information conducted on $11 / 2 / 2018$ in Durumi IDP camp FCT Abuja Nigeria

Key Informant Information conducted on 19/2/2018 in Karmajiji IDP camp FCT Abuja Nigeria

Ladan, M.T. Migration, Trafficking, Human Rights and Refugees under International Law: A case study of Africa. Zaria, Nigeria: Ahmadu Bello University Press (2006)..

Ladan, M.T. Impact of insecurity in the north on internally displaced people and migration flows between Nigeria and neighbouring countries. The Forum of European Union Working Group on Migration and Development. Abuja (2012).

Obikaeze, V. C., \& Onuoha, C. B. "The Nigerian-State and Management of Internally Displaced Persons" (IDPs) From 2012-2016. African Journal of Politics and Society, 4-21. Retrieved from http://www.academix.ng/documents/papers /1484040429_7936.pdf (2016).

UNHCR. "Report of the UNCHR" On the human rights situation in Colombia Organization of Work. Geneva, Switzerland: United Nations High Commissioner for Human Rights (2001).

UNHCR Protecting refugee women: promoting gender. Geneva, Switzerland United Nations High Commissioner for Refugees. Retrieved from http://www.unhcr.org/4de4f71a9.pdf. (2011).

UNHCR Global Trends-Forced displacement in 2016 https://www.unhcr.org/ global trends. (2016)

UNHR Questions and Answers about IDPs. Retrieved January 12, 2018, from United Nations Human Rights: http://www.ohchr.org/ EN/Issues/ IDPersons/ Pages/Issues.aspx. (2018). 